\title{
Structural Properties of Amylopectins Corresponding to Physical Properties of Rice Starches Appropriate for Sake
}

(Received September 30, 2002; Accepted December 9, 2002)

\author{
Jiemei Chen, ${ }^{1}$ Yoshio Nishida ${ }^{2}$ and Makoto Hisamatsu ${ }^{1, *}$ \\ ${ }^{1}$ Laboratory of Food Science and Technology, Faculty of Bioresources, Mie University (1515, Kamihama, Tsu 514-8507, Japan) \\ ${ }^{2}$ Food Research Center, Aichi Industrial Technology Institute (2-2-1, Shinpukuji-cho, Nishi-ku, Nagoya 451-0083, Japan)
}

\begin{abstract}
Starches from a variety of Sake-rice (Yamadanishiki, Gohyakumangoku, Miyamanishiki, Kitanishiki and Wakamizu) which are suitable for Sake brewing were investigated by comparing them with Koshihikari starch to recognize their structural properties of amylopectins. The partial hydrolysate (about $15 \%$ hydrolysis) of starch with isoamylase was fractionated into three fractions (fr.1, fr.2 and fr.3) by gel permeation chromatography (GPC) with a Toyopearl HW-50S, and then the short-amylose chains derived mainly from the outer portion of the amylopectin collected in the fr.3 were analyzed by a HPAEC-system equipped with a pulsed amperometric detector (HPAEC-PAD). From comparison of the chain-length distributions between Sake-rice starches and that of Koshihikari, it was found that Sake-rice amylopectins were plentiful in longish chains around DP 13-23 and scarce in shortish chains around DP 6-12, suggesting a structural property susceptible to retrogradation. The pasting properties of Sake-rice starches analyzed by Rapid Visco Analyzer (RVA) showed higher pasting temperature (PT), higher setback (SB), and lower breakdown (BD) than Koshihikari starch, suggesting the outer portions of amylopectin had abundant longish debranched short sidechains. These results suggested that rice starches with amylopectins susceptible to retrogradation are adequate for Sake-rice.
\end{abstract}

Key words: Sake-rice, amylopectin, chain-length distribution, physical property, RVA, GPC, HPAEC-PAD

Physical properties of starch are important for the qualities of products based on starch and there are many studies on the relationships between information about the fine structures and physical analytical data. ${ }^{1-6)}$ Rice grain, however, is a mixture of amylose, amylopectin, protein, lipid, mineral and so on, and it is not easy to understand their effects on the physical properties. Normal starches consist of amylopectin as the main component, generally $75-85 \%$, and it could be suggested that the differences among fine structures of amylopectins reflect the physical properties of starches, especially starches of the same cultivars. So it is useful to obtain comprehensible analytical data for amylopectin.

Amylopectin is a highly branched and gigantic homopolysaccharide and complete elucidation of its fine structure is impossible at present. From these reasons, a partial hydrolysate of amylopectin with isoamylase has been studied in our laboratory. ${ }^{7-11)}$ The rice starch of Reiho showed a tendency to retrograde more quickly than that of Koshihikari evaluated as good tasting, and the comparative study of Reiho and Koshihikari amylopectins conducted by the analysis method led a suggestion that longish chains were plentiful in the outer portion of Reiho amylopectin and shortish chains were plentiful in outer portion of that of Koshihikari. ${ }^{10)}$ A convenient method has been developed for getting directly this information from starch without separation of amylopectin. ${ }^{7}$

The structural analysis for recognizing physical properties of starch should be verified through more examples. The typical Japanese brew, Sake, is generally produced

\footnotetext{
${ }^{*}$ Corresponding author (Tel.+81-59-231-9614, Fax.+81-59-
} 231-9684, E-mail:hisamats@bio.mie-u.ac.jp). from Yamadanishiki and Gohyakumangoku which are well known as rice suitable for Sake brewing. Their physical properties are different from those of ordinary cooked rice.

In the present study, the pasting properties of some typical Sake-rice starches and the distributions of shortamylose chains in the outer portion of their amylopectins were studied by comparison with Koshihikari starch to inspect the correlation between the amylopectin fine structure and the physical property of rice starch.

\section{MATERIALS AND METHODS}

Materials. All rice cultivars used in this study were obtained from Food Research Center, Aichi Industrial Technology Institute, Japan, and were cultivated in the year 2000 in Japan.

Preparation of starches. Starch was isolated from rice grains by using a cold $0.2 \%$ sodium hydroxide solution according to the alkali method ${ }^{12)}$ with modification. The precipitate was washed with distilled water till the $\mathrm{pH}$ decreased to 7.0 and the protein could not be determined by the Bradford method. ${ }^{13)}$ After being rinsed with ethanol, the starch was dried in the air, and then passed through a 100-mesh sieve.

Preparation of defatted starches. Starch ( $2 \mathrm{~g})$ was suspended in dimethyl sulfoxide $(40 \mathrm{~mL})$, dissolved by shaking at $37^{\circ} \mathrm{C}$ for overnight, poured gently in $100 \mathrm{~mL}$ methanol and left to stand overnight. The precipitate collected on a glass-filter 3G-3 was rinsed successively with methanol and ether, and then dried in the air. The starch powder passed through a 100-mesh sieve was used. 
Preparation of $0.2 \%$ starch solution and partial hydrolysate by isoamylase. A $0.2 \%$ defatted starch solution (15 $\mathrm{mL}$ ) was mixed with $15 \mathrm{mU}$ of Pseudomonas isoamylase (Hayashibara Biochemical Laboratories, Japan) and shaken at $50 \mathrm{rpm}$ at $30^{\circ} \mathrm{C}$.) One isoamylase unit is defined as the amount of enzyme required to produce 1 $\mu$ mol of reducing sugar per min from waxy maize starch. In order to measure a time course of the debranching reaction, partial hydrolysates $(2 \mathrm{~mL})$ taken out continuously from the test tube at appropriate reaction times $(0.5,1$, $1.5,2,2.5$ and $3 \mathrm{~h}$ ) were heated in a boiling water bath for $5 \mathrm{~min}$ to inactivate the enzyme. The reducing power was analyzed by a modified Park-Johnson method ${ }^{14)}$ and the degree of hydrolysis (\%) was calculated by dividing the value of the reducing power of the partial hydrolysate with that of the complete hydrolysate. A complete debranching reaction was conducted with ten isoamylase units $(10 \mathrm{mU} / \mathrm{mL})$ and shaken for 3 days. A time course was prepared from the various partial hydrolysates in each rice starch and used to estimate an appropriate time for preparation of $15 \%$ partial hydrolysate, according to the previous method."

Iodine affinity and amylose content. Iodine affinities of defatted starches were determined according to the method described by Kasemsuwan et al ${ }^{15)}$ Apparent amylose contents were calculated by dividing the iodine affinity of defatted starch by $20 \%{ }^{16)}$ Each analysis was replicated two times at least.

Gel permeation chromatography (GPC) of partial and complete hydrolysates. Ten milliliter of the hydrolysate

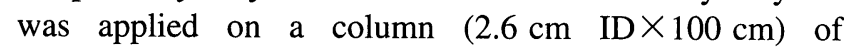
Toyopearl HW-50S (Tosoh Co., Ltd., Japan), and eluted with $50 \mathrm{mM} \mathrm{NaCl}$ containing $0.01 \%$ of $\mathrm{NaN}_{3}$ by using a peristaltic pump on the flow rate of $40 \mathrm{~mL} / \mathrm{h}$. Carbohydrate in each fraction $(5 \mathrm{~mL})$ was estimated by the phenol$\mathrm{H}_{2} \mathrm{SO}_{4}$ method. ${ }^{177}$ The fractions eluted were classified into three fractions (fr.1, fr.2 and fr.3) and the fr.3 sample was concentrated by a rotary evaporator and lyophilized.

Chain-length distribution. Chain-length distribution was determined by HPAEC-PAD according to the method described previously.

Starch pasting properties. The pasting properties of starches sieved with 100-mesh were measured with Rapid Visco Analyzer (RVA, model RVA-3D, Newport Scientific, Australia). Moisture content was determined by drying at $110^{\circ} \mathrm{C}$ for $40 \mathrm{~min}$ to ensure slurry concentrations of $6,8,10$ and $12 \%$ on dry weight basis. Total slurry weight was $30 \mathrm{~g}$. A starch suspension was held at $30^{\circ} \mathrm{C}$ for 6 min, and subsequently heated to $95^{\circ} \mathrm{C}$ at a rate of $13^{\circ} \mathrm{C} /$ min, held at $95^{\circ} \mathrm{C}$ for $6.5 \mathrm{~min}$, cooled down to $30^{\circ} \mathrm{C}$ at a rate of $10.8^{\circ} \mathrm{C} / \mathrm{min}$, and finally held at $30^{\circ} \mathrm{C}$ for $9 \mathrm{~min}$. The suspension was stirred at $160 \mathrm{rpm}$ throughout the experiment. Each analysis took 32.5 min. ${ }^{18,19)}$

\section{RESULTS AND DISCUSSION}

\section{Iodine affinity and amylose content.}

Apparent amylose contents of the defatted starches varied from $12.9 \%$ (Kitanishiki) to $18.1 \%$ (Miyamanishiki) as shown in Table 1. Yamadanishiki and Gohyakumangoku showed the same content $(16.7 \%)$. There were no
Table 1. Iodine affinities and amylose contents of rice starches.

\begin{tabular}{lcc}
\hline Starch & $\begin{array}{c}\text { Iodine affinity } \\
\text { IA }(\mathrm{g} / 100 \mathrm{~g})\end{array}$ & $\begin{array}{c}\text { Apparent amylose } \\
\text { content }(\%)^{*}\end{array}$ \\
\hline Yamadanishiki & 3.35 & 16.7 \\
Gohyakumangoku & 3.34 & 16.7 \\
Miyamanishiki & 3.62 & 18.1 \\
Kitanishiki & 2.58 & 12.9 \\
Wakamizu & 2.86 & 14.3 \\
Koshihikari & 2.79 & 13.9 \\
\hline
\end{tabular}

${ }^{*}$ Calculated by (Iodine affinity IA/20) $\times 100$.

Table 2. Composition of each fraction of complete hydrolysates of rice starches by isoamylase eluted on GPC Toyopearl HW-50S.

\begin{tabular}{lcccc}
\hline \multirow{2}{*}{ Starch } & \multicolumn{3}{c}{ Total saccharide ratio (\%) } \\
\cline { 2 - 3 } & Amylose & & \multicolumn{2}{c}{ Amylopectin } \\
\cline { 2 - 3 } \cline { 5 - 5 } & fr.1 & & fr.2 & fr.3 \\
\hline Yamadanishiki & 16.5 & & 22.1 & 61.4 \\
Gohyakumangoku & 16.9 & & 23.4 & 59.7 \\
Miyamanishiki & 17.3 & & 24.5 & 58.3 \\
Kitanishiki & 13.1 & & 23.0 & 64.0 \\
Wakamizu & 14.9 & & 28.7 & 56.5 \\
Koshihikari & 14.0 & & 22.9 & 63.1 \\
\hline
\end{tabular}

obvious differences between Koshihikari and Kitanishiki and Wakamizu in amylose contents.

\section{GPC of partial and complete hydrolysates on Toyopearl HW-50S.}

GPC profiles of the partial and complete hydrolysates of starches are shown in Fig.1. The fractions eluted were classified into three fractions (fr.1, fr.2 and fr.3) by referring elution pattern of completely debranched rice starch in each case, and the data for the three fractions are shown in Table 2. An approximate content of amylose was also estimated from the fr. 1 and it was found that the results were similar to the apparent amylose contents determined by the iodine affinity method. On the partial hydrolysate, halfway hydrolysate of amylopectin was eluted in fr. 1 and the debranched short side-chains in the amylopectin released were accumulated in fr.3. The debranched short side-chains in amylopectin could be considered to be very minor in the partial hydrolysate ${ }^{7)}$ and almost all chains eluted in the lower molecular side at fr.3 could be speculated to be chains released from the outer layer of the amylopectin.

\section{Chain-length distributions of the fr.3.}

Chain-length distributions of fr. 3 in the GPC of partial hydrolysates were analyzed by HPAEC-PAD and those of Yamadanishiki, Gohyakumangoku, Miyamanishiki, Kitanishiki and Wakamizu were compared with that of Koshihikari (Fig.2). From the results, it could be estimated that amylopectins of Sake-rice starches have characteristic structures with a large amount of longish chains (DP 1323) and a small amount of shortish chains (DP 6-12).

\section{Starch pasting properties.}

As shown in Fig.3, RVA viscograms obtained for rice defatted starch at different slurry concentrations indicated 

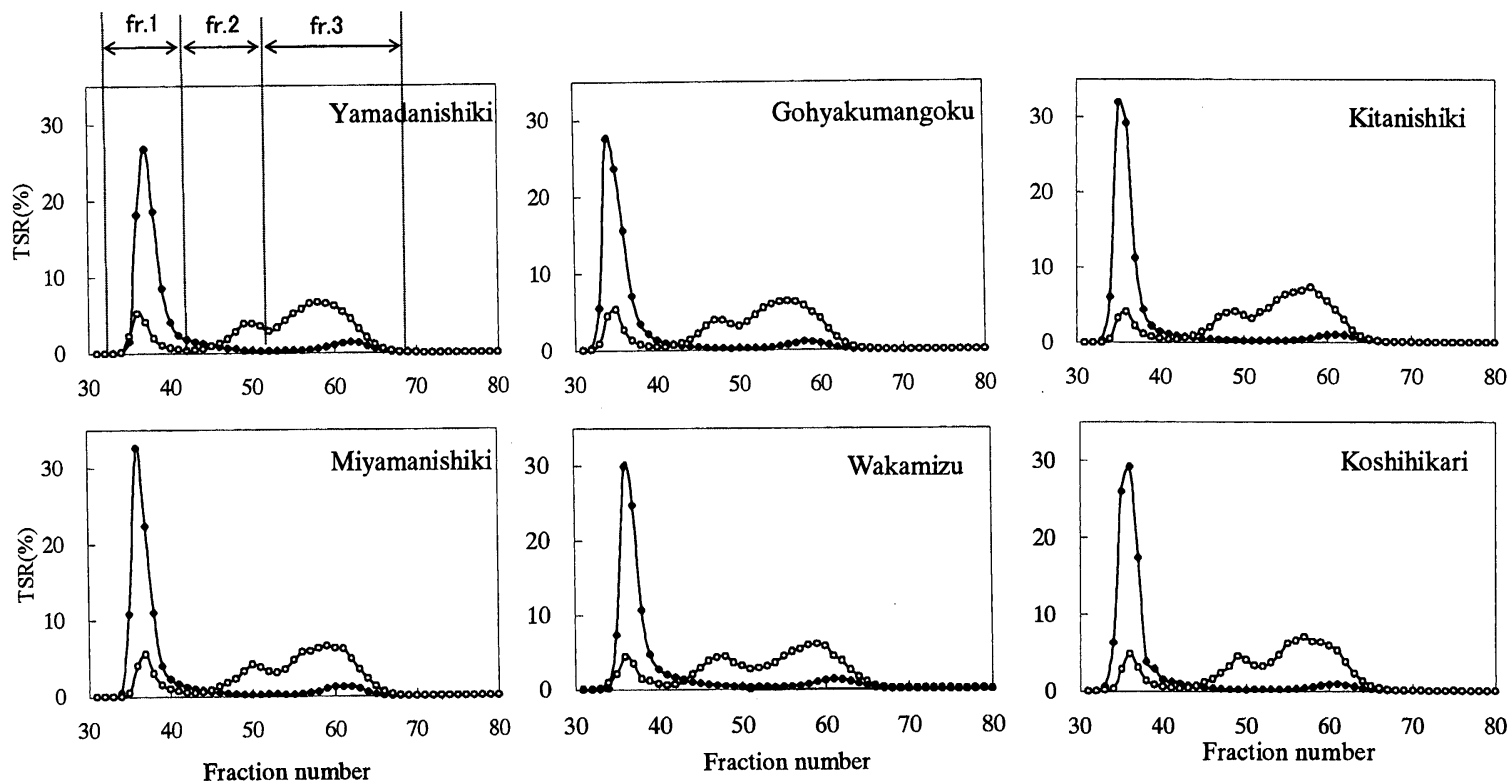

Fig. 1. Gel permeation chromatography (GPC) of partial $(\bullet)$ and complete hydrolysates $(\bigcirc)$ of rice starches with isoamylase on the column of Toyopearl HW-50S.

The three fractions (fr.1, fr.2 and fr.3) were divided by considering the three peaks on the elution pattern of the complete hydrolysate.
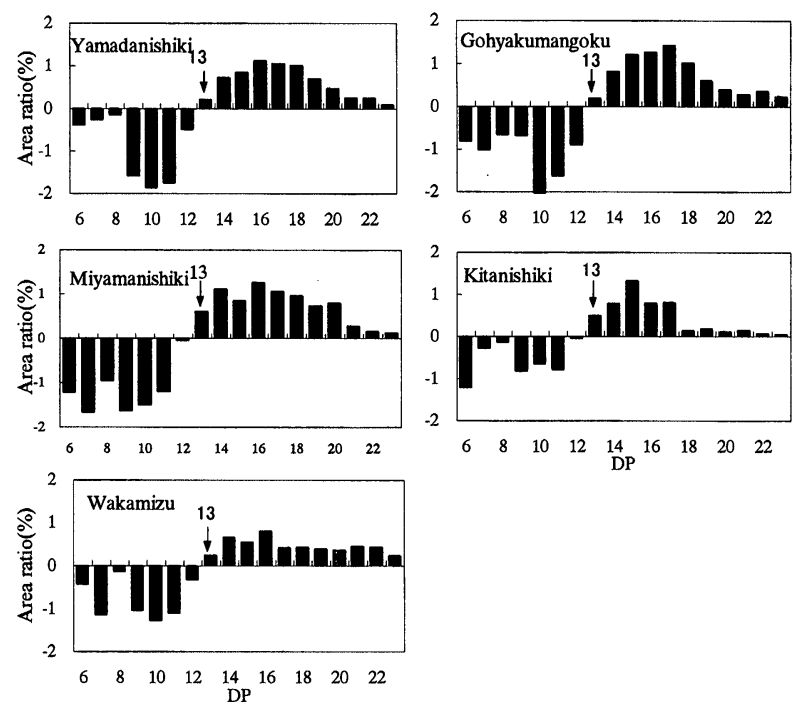

Fig. 2. Differences of debranched short side-chains in amylopectin between fr.3 of Sake-rice starches and fr.3 of Koshihikari starch.

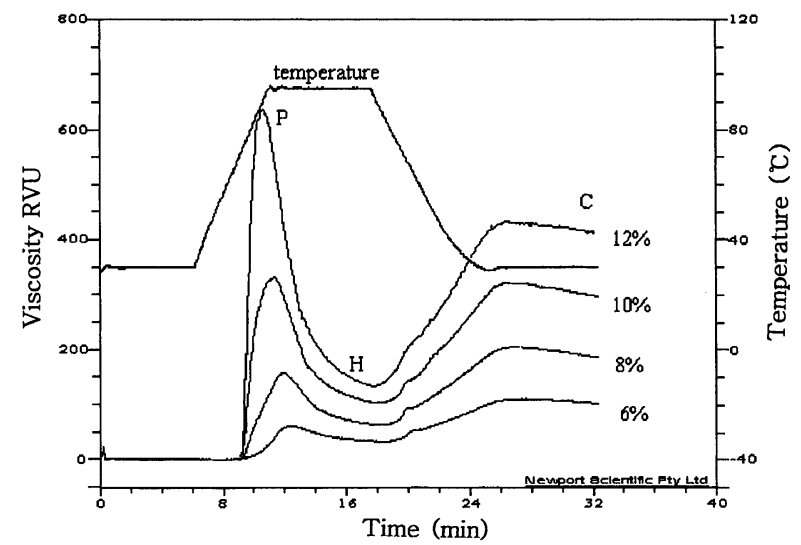

Fig. 3. Rapid viscogram patterns of Yamadanishiki starch at various concentrations.

$\mathrm{P}$, peak viscosity (maximum paste viscosity); $\mathrm{H}$, hot paste viscosity (minimum paste viscosity); C, cold paste viscosity (final viscosity).
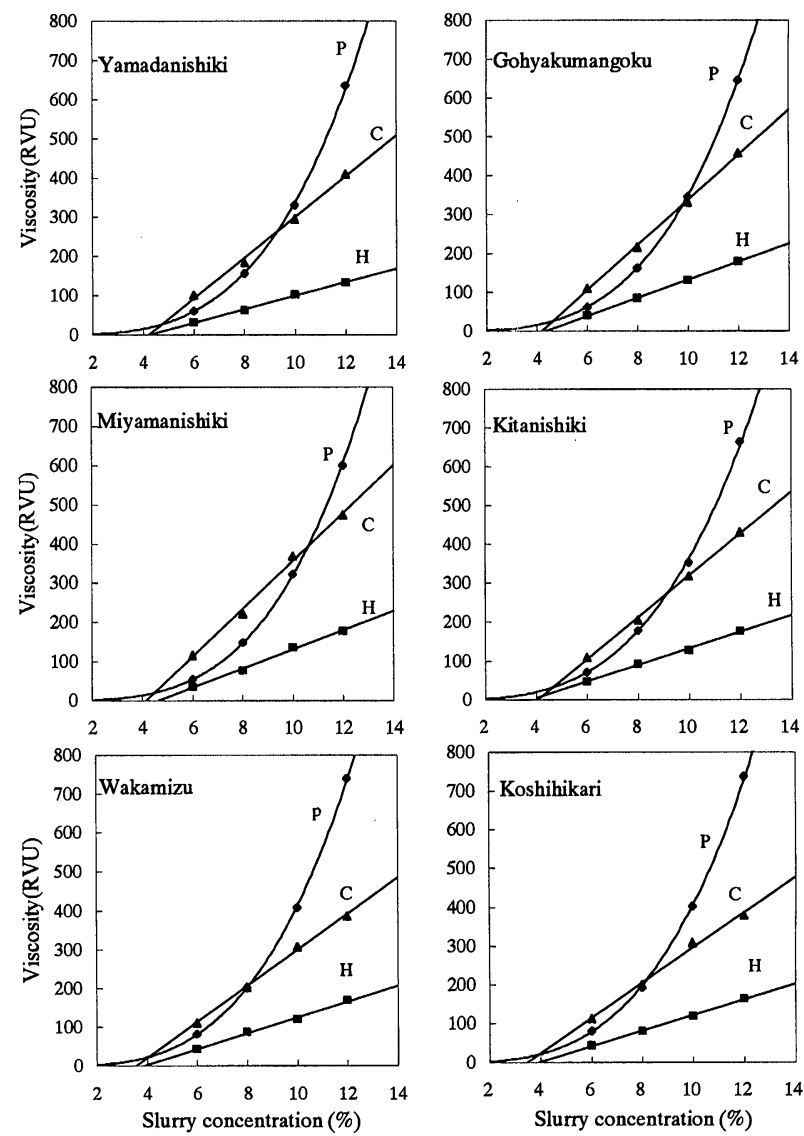

Fig. 4. Viscogram parameters of Sake-rice starches and Koshihikari starch at various concentrations.

Symbols $\mathrm{P}, \mathrm{H}$ and $\mathrm{C}$ are explained in Fig. 3.

a variety of patterns. When the slurry was heated, the granules began to swell and paste at pasting temperature (PT, the temperature when the viscosity reached onetwentieth of the difference between the initial viscosity and the maximum viscosity). The viscosity increased and reached the peak viscosity $(\mathrm{P}$, maximum paste viscosity achieved in the heating stage of the profile) until the 
Table 3. Pasting viscosity parameters of rice starches at different concentrations.

\begin{tabular}{|c|c|c|c|c|c|c|c|c|c|c|c|c|}
\hline \multirow{2}{*}{ Starch } & \multicolumn{4}{|c|}{$\mathrm{PT}^{* 1}\left({ }^{\circ} \mathrm{C}\right)$} & \multicolumn{4}{|c|}{$\mathrm{P}^{* 2}(\mathrm{RVU})$} & \multicolumn{4}{|c|}{$\mathrm{H}^{* 3}(\mathrm{RVU})$} \\
\hline & $6 \%$ & $8 \%$ & $10 \%$ & $12 \%$ & $6 \%$ & $8 \%$ & $10 \%$ & $12 \%$ & $6 \%$ & $8 \%$ & $10 \%$ & $12 \%$ \\
\hline Yamadanishiki & 86.3 & 72.4 & 71.0 & 69.7 & 60 & 157 & 331 & 635 & 38 & 73 & 117 & 157 \\
\hline Gohyakumangoku & 89.5 & 75.1 & 73.3 & 72.1 & 61 & 162 & 345 & 646 & 39 & 83 & 130 & 179 \\
\hline Miyamanishiki & 90.6 & 73.4 & 71.6 & 69.8 & 53 & 148 & 322 & 599 & 33 & 76 & 135 & 177 \\
\hline Kitanishiki & 84.6 & 74.3 & 66.3 & 65.5 & 70 & 177 & 352 & 663 & 45 & 91 & 127 & 176 \\
\hline Wakamizu & 82.9 & 75.2 & 73.3 & 72.5 & 81 & 201 & 408 & 740 & 43 & 86 & 119 & 169 \\
\hline Koshihikari & 68.9 & 68.0 & 66.3 & 65.5 & 80 & 193 & 402 & 737 & 43 & 79 & 118 & 164 \\
\hline \multirow{2}{*}{ Starch } & \multicolumn{4}{|c|}{$\mathrm{C}^{* 4}(\mathrm{RVU})$} & \multicolumn{4}{|c|}{$\mathrm{BD}^{* 5}(\mathrm{RVU})$} & \multicolumn{4}{|c|}{$\mathrm{SB}^{* 6}(\mathrm{RVU})$} \\
\hline & $6 \%$ & $8 \%$ & $10 \%$ & $12 \%$ & $6 \%$ & $8 \%$ & $10 \%$ & $12 \%$ & $6 \%$ & $8 \%$ & $10 \%$ & $12 \%$ \\
\hline Yamadanishiki & 105 & 196 & 311 & 421 & 23 & 84 & 213 & 479 & 67 & 124 & 193 & 265 \\
\hline Gohyakumangoku & 109 & 216 & 332 & 457 & 22 & 79 & 215 & 467 & 70 & 132 & 202 & 279 \\
\hline Miyamanishiki & 115 & 222 & 369 & 474 & 20 & 72 & 187 & 423 & 82 & 146 & 234 & 297 \\
\hline Kitanishiki & 109 & 205 & 317 & 430 & 25 & 86 & 226 & 488 & 64. & 115 & 190 & 312 \\
\hline Wakamizu & 111 & 202 & 307 & 386 & 38 & 115 & 289 & 571 & 67 & 116 & 188 & 217 \\
\hline Koshihikari & 113 & 199 & 308 & 379 & 37 & 114 & 284 & 573 & 70 & 120 & 190 & 215 \\
\hline
\end{tabular}

Slurry concentration was adjusted by dry weight basis of starch. ${ }^{* 1}$ Pasting temperature (PT), ${ }^{* 2}$ peak viscosity $(\mathrm{P}),{ }^{* 3}$ hot paste viscosity $(\mathrm{H}),{ }^{* 4}$ cold paste viscosity (C), ${ }^{* 5}$ breakdown (BD), P-H, ${ }^{* 6}$ setback (SB), C-H.

Table 4. Pasting viscosity parameters* of rice starches at 200 RVU of peak viscosity.

\begin{tabular}{lccccc}
\hline Starch & $\begin{array}{c}\text { Slurry } \\
(\%)\end{array}$ & $\begin{array}{c}\mathrm{H} \\
(\mathrm{RVU})\end{array}$ & $\begin{array}{c}\mathrm{C} \\
(\mathrm{RVU})\end{array}$ & $\begin{array}{c}\mathrm{BD} \\
(\mathrm{RVU})\end{array}$ & $\begin{array}{c}\mathrm{SB} \\
(\mathrm{RVU})\end{array}$ \\
\hline Yamadanishiki & 8.6 & 88 & 235 & 112 & 147 \\
Gohyakumangoku & 8.5 & 96 & 250 & 104 & 154 \\
Miyamanishiki & 8.7 & 99 & 279 & 101 & 180 \\
Kitanishiki & 8.3 & 95 & 229 & 105 & 134 \\
Wakamizu & 8.0 & 83 & 204 & 117 & 121 \\
Koshihikari & 8.0 & 85 & 206 & 119 & 124 \\
\hline
\end{tabular}

Symbols $\mathrm{H}, \mathrm{C}, \mathrm{BD}$ and $\mathrm{SB}$ are explained in Table $3 .^{*}$ All parameters were calculated at $200 \mathrm{RVU}$ of peak viscosity by using the figures shown in Fig. 4.

swollen granules burst, and then decreased quickly to the base level of hot paste viscosity $(\mathrm{H}$, minimum paste viscosity achieved after holding at the maximum temperature). When the gelatinized starch was cooled with tap water, the viscosity increased again through retrogradation. $\mathrm{C}$ is the cold paste viscosity (or final viscosity, the viscosity at the end of run). $\mathrm{P}-\mathrm{H}$ is the breakdown (BD), and $\mathrm{C}-\mathrm{H}$ is the setback (SB). The PT, P, H, C, BD and SB for starches tested at $6,8,10$ and $12 \%$ slurries are summarized in Table 3 . These data seem to show tendencies in the physicochemical properties of Sake-rice starch. Many PT, BD and SB values of Sake-rice starches were higher, lower and higher than that of Koshihikari, respectively. As the SB values could be speculated to be related with retrogradation, the higher SB values of Sake-rice starches at high concentrations led to the similar speculation for Sake-rice amylopectins in HPAEC-PAD. However, they had somewhat complicated and incoherent contents indicated with shaded boxes in Table 3 .

To understand more clearly the correlation between the pasting property and amylopectin fine structure, the viscosity parameters of $\mathrm{P}, \mathrm{H}$ and $\mathrm{C}$ were plotted against the slurry concentration according to a report by K.R. Bhattacharya et al. ${ }^{20)}$ and V. Singh et al. ${ }^{4)}$ Using the curves shown in Fig. 4, the values of slurry concentration, H, C,
$\mathrm{BD}$ and SB were calculated at a peak viscosity of 200 RVU and summarized in Table 4. It was found that the BD of Wakamizu was almost no different from that of Koshihikari, and those of other Sake-rice starches were lower than that of Koshihikari. According to the results of Xian-Zhong Han et al. ${ }^{2)}$ the proportion of long chains of amylopectin was negatively correlated and the proportion of short chains of amylopectin was positive correlated with BD. The BD value of Sake-rice agreed with that. Miyamanishiki, Gohyakumangoku and Yamadanishiki showed clearly higher values for SB, and Kitanishiki, Wakamizu and Koshihikari showed lower values for SB. The SB value had a positive correlation with amylose content of starch, as discussed, ${ }^{21)}$ but it is also important to consider the characteristics of amylopectin structure. It could be understood that the typical Sake-rice starches have unique amylopectins with plentiful longish chains and scare shortish chains.

This study was supported in part by a Grant for Scientific Research from Iijima Memorial Foundation for Promotion of Food Science and Technology.

\section{REFERENCES}

1 ) C.M.L. Franco, K.S. Wong, S.H. Yoo and J. Jane: Structural and functional characteristics of selected soft wheat starches. Cereal Chem., 79, 243-248 (2002).

2 ) X.-Z. Han and B.R. Hamaker: Amylopectin fine structure and rice starch paste breakdown. J. Cereal Sci., 34, 279-284 (2001).

3 ) S.H. Yoo and J. Jane: Structural and physical characteristics of waxy and other wheat starches. Carbohydr. Polym., 49, 297305 (2002).

4 ) V. Singh, H. Okadome, H. Toyoshima, S. Isobe and K. Ohtsubo: Thermal and physicochemical properties of rice grain, flour and starch. J. Agric. Food Chem., 48, 2639-2647 (2000).

5 ) T. Sasaki, T. Yasui and J. Matsuki: Effect of amylose content on gelatinization, retrogradation, and pasting properties of starches from waxy and nonwaxy wheat and their $F_{1}$ seeds. Cereal Chem., 77, 58-63 (2000). 
6 ) J. Jane, Y.Y. Chen and L.F. Lee: Effects of amylopectin branch chain length and amylose content on the gelatinization and pasting properties of starch. Cereal Chem., 76, 629-637 (1999).

7 ) T.C. Sunarti, N. Yoshio and M. Hisamatsu: Direct analysis of chains on outer layer of amylopectin through partial hydrolysis of normal starch by isoamylase. J. Appl. Glycosci., 48, 123$130(2001)$

8 ) T.C. Sunarti, T. Nunome, N. Yoshio and M. Hisamatsu: Study on chains released from amylopectin between immobilized and free debranching enzymes. J. Appl. Glycosci., 48, 1-10 (2001).

9 ) M. Hisamatsu, M. Hirata, A. Sakamoto, K. Teranishi and T. Yamada: Partial hydrolysis of waxy maize amylopectin by isoamylase immobilized on magnetic support. Starch/Stärke, 48, 6-9 (1996).

10) N. Yoshio, Q. Lin, M. Hisamatsu, K. Teranishi, T. Yamada and I. Maeda: Comparative study on amylopectin molecules of Koshihikari and Reiho (Oryza sativa L. japonica). J. Appl. Glycosci., 44, 169-173 (1997).

11) N. Yoshio, I. Maeda, K. Teranishi, M. Hisamatsu and T. Yamada: Molecular structures and properties of starches from different cultivars of rice (Oryza sativa L. japonica) produced in Japan. Oyo Toshitsu Kagaku, 42, 365-374 (1995).

12) K. Yamamoto, S. Sawada and T. Onogaki: Properties of rice starch prepared by alkali method with various conditions. Denpun Kagaku, 20, 99-104 (1973).

13) M.M. Bradford: A rapid and sensitive method for the quantitation of microgram quantities of protein utilizing the principle of protein-dye binding. Anal. Biochem., 72, 248-254 (1976).

14) S. Hizukuri, Y. Takeda, M. Yasuda and A. Suzuki: Multibranched nature of amylose and the action of debranching enzymes. Carbohydr. Res., 94, 205-213 (1981).

15) T. Kasemsuwan, J. Jane, P. Schnable, P. Stinard and D. Robertson: Characterization of the dominant mutant amyloseextender (Ael-5180) maize starch. Cereal Chem., 72, 457-464 (1995).

16) Y. Takeda, S. Hizukuri and B.O. Juliano: Structures of rice amylopectins with low and high affinities for iodine. Carbohydr. Res., 168, 79-88 (1987).

17) M. Dubois, K.A. Gilles, J.K. Hamilton, P.A. Rebers and F. Smith: Colorimetric method for determination of sugars and related substances. Anal. Chem., 28, 350-356 (1956).

18) A. Becker, S.E. Hill and J.R. Mitchell: Milling-a further parameter affecting the rapid visco analyzer (RVA) profile. $\mathrm{Ce}$ real Chem., 78, 166-172 (2001).

19) I.L. Batey and B.M. Curtin: Effects on pasting viscosity of starch and flour from different operating conditions for the rapid visco analyzer. Cereal Chem., 77, 754-760 (2000).

20) K.R. Bhattacharya and C.M. Sowbhagya: Pasting behavior of rice: A new method of viscography. J. Food Sci., 44, 797-804 (1979).

21) M. Asaoka, A. Nakayama, J. Endo, N. Inouchi and H. Fuwa: Gelatinization properties of endosperm starch of new types of rice grains: Nonwaxy types of rice harvested in 1990 and 1991. Oyo Toshitsu Kagaku, 41, 25-33 (1994).

\section{清酒に適した米澱粉の物性に対応する アミロペクチンの構造特性}

陳 潔梅 ${ }^{1}$, 西田淑男 ${ }^{2}$, 久松 眞 ${ }^{1}$

1 三重大学生物資源学部食品資源工学研究室

（514-8507 津市上浜町 1515）

2 愛知県食品工業技術センター

(451-0083 名古屋市西区新福寺町 2-1-1)

酒米に使用されている山田錦, 五百万石, 美山錦, 北 錦, 若水の澱粉について, アミロペクチンの構造特性を 理解するため,コシヒカリと比較した。澱粉溶液に直接 イソアミラーゼを作用させて約 $15 \%$ 部分加水分解物を調 製し, Toyopearl HW-50Sによるゲルクロマトグラフィー で3区分（fr.1，fr.2，fr.3）に分けた。fr.3に分画された アミロペクチンの外層から主に切り出された短鎖アミ ロースを HPAEC-PADで分析した. 酒米とコシヒカリの 鎖長分布を比較したところ，酒米のアミロペクチンはDP 13-23 付近の長めの鎖長が多く, DP 6-12 付近の短めの鎖 長が少なく，老化しやすい構造特性であると推測した. 次にRVAを使用し酒米の物性特性を調べた結果，酒米は 高い糊化開始温度，高いセットバック值，低いブレーク ダウン值を示し，アミロペクチンの外層部には長めの短 鎖アミロースが多く存在すると推察された。これらの結 果から, 老化しやすいアミロペクチン構造を有した米澱 粉が酒米に適していると考えられた。 